\title{
Н.Р. Байжанова
}

Новосибирский государственный университет

\section{О вариативности алтайских паремий в дискурсе ${ }^{1}$}

Цель этой статьи - выявить вариативные особенности алтайских пословиц и поговорок в речи. Вопрос о варьировании паремий является частью общей проблемы варьирования устных фольклорных текстов. В фольклористике термином 'текст' обозначают разные его формы: письменный и устный. Фольклорный текст - это и дискурс одновременно. К.В. Чистов по этому поводу пишет: «Основная форма бытия фольклорного текста устная. Фиксация его - более или менее случайный эпизод, очень важный для фольклориста, но не играющий существенной роли в истории фольклора» [Чистов, 2005, с. 54]. Любой фольклорный текст является «продуктом» речи и он должен рассматриваться как итог речемыслительной деятельности его создателя, воплощающего особый замысел в его направленности на определенного слушателя /читателя.

Естественной формой бытования паремий является речь, или дискурс. Изучение алтайских паремий без обращения к их речевому контексту затрудняет исследование таких вопросов, как устойчивость и стабильность пословичной традиции, изменчивость содержания и формы этих текстов во времени. Изучение паремий в дискурсе позволяет исследователю зафиксировать новые пословицы и сопоставить их с записями, сделанными предшественниками, и выявить корпус текстов устойчиво сохраняющихся во времени, а также изменения, произошедшие с теми или иными паремиями.

Таким образом, наличие у пословиц письменной и устной форм позволяет нам в функциональном плане изучать их в двух взаимосвязанных между собой аспектах: 1) динамический аспект, исследующий их функционирование в речи; 2) статический аспект, отражающий стабильные инвариантные особенности этих текстов. Анализ дискурсивных особенностей пословиц предполагает их изучение в динамике, в речи, в тех условиях, когда конкретизации подвергаются все почти «скрытые» стороны текста.

Алтайские пословицы и поговорки, как и любые другие фольклорные тексты, обладая стереотипной структурой (для них характерна двучастность, симметричная конструкция, определенная ритмическая модель), варьируется в речи по определенным правилам. При этом у них может видоизменяться и форма, и содержание.

При использовании текста в речи исполнитель может сознательно видоизменить текст в зависимости от ситуации. Поскольку минимальные фольклорные тексты: пословицы и поговорки - воспроизводятся обычно в разовом контексте (монологическом или диалогическом), то каждое их воспроизведение является одновременно адаптацией к этому разовому контексту. Вариативность этих текстов можно объяснить и определенными свойствами человеческой памяти. Г.Ф. Благова правильно замечает, что у пословичного текста существуют «стабилизаторы», т.е. опорные слова, и средний смысл пословицы; варьирование пословиц зависит

\footnotetext{
${ }^{1}$ Статья подготовлена при финансовом содействии гранта Президента РФ для поддержки ведущих научных школ РФ НШ-8418.2006.6.
} 
от того, насколько точно запомнил их субъект речи. Как правило, точному запоминанию подвергается основная ядерная смысловая часть, периферийная часть, где пословичное предложение оформляется грамматически, не запоминаются, и поэтому в речи образуются варианты [Благова, 2000]. Этот средний смысл паремий большинство исследователей называют «инвариантный смысл», другие логемой [Савенкова, 2002], когнитемой [Иванова, 2003]. Системное изучение нашего материала показывает устойчивость таких инвариантов при вариативности паремий в речи. Они заключают в себе концептуальные (понятийные) знания народа. И передача этих знаний во времени тесно связана с памятью этноса, его ментальностью, поэтому изучение паремий в дискурсе предполагает учет их когнитивного аспекта.

Наши наблюдения за алтайскими паремиями в дискурсе показывают, что они в основном варьируются на их поверхностном уровне: на орфоэпическом, лексическом, морфологическом, синтаксическом и композиционном. Это может быть связано как с индивидуальными способностями памяти исполнителей, с тем, как они запомнили ту или иную пословицу, так и с этногрупповыми, диалектными особенностями. Рассмотрим эти разновидности варьирования паремий более подробно.

При лексическом варьировании возникают, как правило, синонимические отношения между варьирующимися лексемами. Варьирование пословичных текстов на поверхностном уровне не приводит к изменению их семантического плана. Приведем примеры: 1) Јаман ат семирзе, јаньна кӧнӧк буулатпас, / Јаман кижи байыза, јанына айыл тургуспас [2; 3] - Худой конь ожиреет - не даст к бедру ведро привязать, / Худой человек разбогатеет - не даст рядом юрту поставить; 2) $\mathrm{Ja}$ ман ат тойынза, јалмажына кӧнӧк буулатпас, / Јаман кижи јаранза, јанына айыл тургуспас [9] - Плохой конь ожиреет - не даст к седлу ведро привязать, / Плохой человек разбогатеет - не даст рядом юрту поставить; 3) Јокту кижи тойынза, јанына айыл отургуспас, / Јаман тору семирзе, јалмажына борбуй буулат$n a c[10]$ - Бедный человек насытится - рядом юрту не даст поставить, / Худой конь ожиреет - к бедру бурдюк не даст привязать.

В последней пословице употреблены диалектные слова: тору 'конь', борбуй ‘бурдюк', сделанный из кожи животного, традиционная домашняя утварь, и в современности сохраняющаяся в хозяйстве теленгитов.

Многие пословицы, встречающиеся в речи носителей южных диалектов Алтая, присутствуют в речи носителей северных диалектов: в челканском, кумандинском. Различия вариантов проявляются в фонетических и лексических особенностях, которые существенно не влияют на смысл пословиц. Например: алт. Јылмай сууда бальк бар, / Jылмайганда кылькк бар [2; 3] - В текучей реке рыба есть, / У двуличного норов есть; Јылмай сууда балык бар, / Јылмадыкта кылык бар [11] - В текучей реке рыба есть, / У двуличного норов есть. челк. Tbblльг сугде балькк кӧn, / Тьылвайганда кылык кӧn - В теплой воде рыбы много, / У тихони характеру много. Согласному г в челканском диалекте соответствует в алтайском долгий согласный $y y$, представляющий собой результат стяжения согласного 2 с соседним гласным (таг - myy, cyz - cyy, mbылыс - алт. јылу). М.Ч. Чумакаева отмечает, аналогичное же явление наблюдается в диалектах туба, кумандинском, в тувинском и хакасском языках [Чумакаева, 1988, с. 4]. Вариант этой пословицы присутствует в пословичном фонде тувинцев, где согласная 2 также сохранена: Чымааргайда ужур-ла бар, / Чылбай сугда байла v-на бар. - В теплом омуте мальки водятся, / В тихоне что-то таится [5]. Это свидетельствует либо о близких контактах этих соседних этносов, либо о существовании в прошлом общетюркского паремиологического фонда.

Приведем пример грамматического варьирования паремии: Мажак јок арба ка кайар [3] - Без колосьев ячмень торчит; Мажак јок арба ка кайар - Ячмень 
без колосьев торчит. Здесь различаются формы глагольных сказуемых: в первом примере дана синтетическая форма, во втором - аналитическая форма (ка ккайар каукайыл калар).

При варьировании пословицы изменения могут происходить одновременно на фонетическом (орфоэпическом), лексическом и грамматическом уровнях: Кижи тоны кирчи, / Кижи ады терчи - Чужое пальто маркое, / Чужой конь потливый [4]; Кижи киими кирчил, / Кижи маль терчил [8] - Чужая одежда маркая, / Чужой конь потный; Кижи кийими кирлеvкей, / Кижи ады терле ккей [6] - Одежда человека маркая, / Лошадь человека потная. В этих примерах присутствуют следующие лексические замены, различающиеся родо-видовыми отношениями:

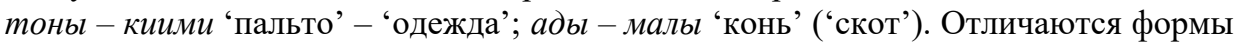
сказуемых, выраженных прилагательными (кирчи / кирчил / кирлеvкей). На уровне орфоэпии варьируются киими / кийими.

При синтаксическом варьировании пословицы изменения могут касаться

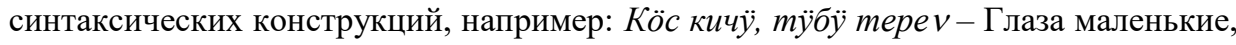
дно их глубокое [4]; Кӧзи кичинек те болзо, / Је тӥби оныv тереv [3] - Хоть и глаза маленькие, / Но дно их глубокое.

При композиционном варьировании пословицы может произойти перестановка частей двухчастной пословицы, например: Байдаv једер, / Майдаv тамар От богатого достанется, / От масла капнет [4]; Ÿсmev maмap, / Байдаv једер - C масла капнет, / От богатого достанется [13].

Компрессия, или сокращение объема пословицы, характерна для параллелизмов. Как известно, в свое время А.Н. Веселовский рассматривал параллелизм, с одной стороны, как материал для воссоздания общей картины развития поэтического мышления, а с другой - как видоизменяющуюся композиционную форму, служащую основой возникновения ряда других изобразительно-выразительных средств (метафор, символов) [Веселовский, 1989]. Параллельные синтаксические структуры в пословице могут подвергаться компрессии. При утрате второй части параллелизма образное значение переносится на его первую часть, таким образом, происходит метафоризация. В таких пословицах вся смысловая нагрузка переходит на образную ее часть. Так, при сопоставлении алтайских и тувинских пословиц оказалось, что в алтайских одночастных пословицах произошла утрата второй части пословицы. При этом произошло сокращение объема пословиц, компрессия избыточной информации:

алт. Кертеш ле неме тӧӧ эмес [1]

тув. Хертеш-ле чуве теве эвес,

Кемниг-ле чуве мен эвес [5]

алт. Борсук калјанын бодонбос [1]

тув. Боду бодун билинмес,

Борзук калчанын билбес [5].
Не всякий горбатый - верблюд.

Не всякий горбатый - верблюд,

Не всякий виноватый - я.

Барсук своей лысины не замечает.

Плохой своих недостатков не знает,

Барсук о своей лысине не знает.

Приведем пример развертывания пословицы за счет введения дополнительных деталей или дополнительной информации: Чечени лле чет кезип болбозы $v$ [2] - Своим остроумием лиственницу не срубишь; Чечени vле чет кеспези v, / Чеги vле myy aшnaзы v - Своим остроумием молодую лиственницу не срубишь, / Своей добропорядочностью гору не перевалишь.

Появление нового лексического компонента в пословице может привести к изменению всего смысла пословицы. В этом случае следует говорить уже не о вариантах, а о самостоятельных единицах, функционирующих в разных ситуациях. При этом происходит семантическое варьирование, например: Кижи бӱткенде, атту болор, / Кийик бӥткенде, мӥусту болор [7] - Если человек рождается, будет иметь имя, / Если зверь рождается, будет иметь рога; Кийик болзо, тӥктӥ болор, / 
Кижи болзо, јӧптӥ болор - Зверь должен иметь шерсть / Человек должен быть дружелюбным [8]. В первой пословице говорится о том, что всякий человек должен быть с именем, во второй - о том, что человек должен уметь соглашаться. Здесь произошло изменение смысла пословицы за счет слова јӧптӥ 'дружелюбный’. Данный пример показывает, как изменение семантики пословичных текстов в дискурсе может повлечь за собой изменение их прагматической функции.

Изучение паремий в дискурсе позволяет выявить также их контекст употребления. Это можно увидеть на примере паремий, связанных с традициями материнского родового строя, существовавших в прошлом у всех тюркских народов (шорцев, тубаларов, телеутов, алтайцев и т.д.). По традиции важную роль в воспитании племянника играл дядя со стороны матери. При достижении совершеннолетия он обязан был сделать своему племяннику подарок. Какой именно подарок должен был быть - это зависело от материального состояния дяди. Племянник мог даже через суд зайсанов отобрать у своего дяди его скот. Так, по этому поводу употреблялась пословица: “Jeen kelgenče, jetti börÿ kelzin [Дыренкова, 1937, c. 28] - Чем племянник придет, / Пусть лучше семь волков придут (перевод наш). В настоящее время поговорки об отношениях дяди и племянника также присут ствуют в языке старшего поколения алтайцев, например: Јети јеен келзе, јети кой јиир, / Јети бӧрӥ келзе, бирӥни јиир [14] - Придут семь племянников, семь овец съедят, / Придут семь волков, одного съедят; Јееним келгенче, јети бӧрӥ келзе mорт [15] - Чем придет племянник мой, пусть лучше семь волков придут. Свой изначальный контекст эти пословицы утратили, поскольку исчезли сама традиция. Данный факт свидетельствует о том, что паремии, связанные с некоторыми обычаями и обрядами, существовавшими в прошлом и утраченными ныне, также забываются или, приспосабливаясь к современным условиям, видоизменяются, сужают свои значения.

Итак, исследование паремий в дискурсе позволяет выявить степень сохранности традиции, передаваемость этих текстов во времени, а также контекст их употребления. Описывая вариативность алтайских паремий, мы пришли к выводу о том, что народные знания, отраженные в этих текстах, сохраняются благодаря устойчивости их смыслов. Варьированию подвергается лишь поверхностный уровень этих текстов.

\section{Литература}

Благова Г.Ф. Пословица и жизнь. Личный фонд русских пословиц в историко-фольклористической ретроспективе. М., 2000.

Веселовский А.Н. Психологический параллелизм и его формы в отражениях поэтического стиля // Историческая поэтика. М., 1989.

Дыренкова Н.П. Пережитки материнского рода у алтайских тюрков // Советская этнография. 1937. № 4.

Иванова Е.В. Пословичная концептуализация мира (на материале английских и русских пословиц): Дисс. на соиск.уч.ст. ... докт. филол. наук. СПб., 2003.

Савенкова Л.Б. Русская паремиология: семантический и лингвокультурологический аспекты. Ростов-на-Дону, 2002.

Чистов К.В. Текст письменный - текст устный // Фольклор. Текст. Традиция. Сборник статей. М., 2005.

Чумакаева М.Ч. Введение // Алтайский фольклор. Горно-Алтайск, 1988.

\section{Список источников}

Алтайские пословицы (Алтай кеп-сӧстӧр) / Сост. Л.В. Кокышев. Горно-Алтайск, 1959. 

956.

Алтайские пословицы и поговорки / Сост. С.С. Суразаков. Горно-Алтайск,

Алтайские благопожелания (Алтайдыv алкыштары) / Сост. Б.Я. Бедюров. Горно-Алтайск, 1985.

Вербицкий В.И. Алтайские инородцы. М., 1893.

Тувинские пословицы и поговорки / Сост. М. Хадаханэ, О. Саган-Оол. Кызыл, 1966.

Тыдыков А. Сказки байатов (Байат чорчоктор). Горно-Алтайск, 1994.

Улагашев Н.У. Кокин-Эркей // Алып-Манаш: Алтайские героические сказания. Горно-Алтайск, 1985.

Черноева Н. Баадай Кара. Алтай баатырлар. Горно-Алтайск,1964.

Архивные материалы Института алтаистики (далее - ИА) Республики Алтай (далее - РА). ФМ 1955 г.

Архивные материалы ИА, записи 1984 г. К.И. Максимова - носителя телеутского диалекта. ФМ 359.

Архивные материалы ИА, записанные К.Е. Укачиной в 1985 г. в с. Белтир. Инф. Саблакова Т., Барбачакова Л.Б., Попошева К.А. ФМ 377.

Архивные материалы ИА, записанные В.П. Ойношевым в с. Сугаш в 1988 г. Инф. Иркитова Д.

Полевая запись автора 2004 г. Инф. Белешева Д., с. Хабаровка Онгудайского района РА.

Полевая запись автора 2004 г. Инф. Емекеева Э.Н., с. Хабаровка Онгудайского района РА.

Полевая запись автора 2004 г. Инф. Сартакова С.И., с. Улаган Улаганского района РА.

Полевая запись автора 2005 г. Инф. Кудачинова Ч.С., с. Кокаря Кош-Агачского района РА.

Полевая запись автора 2006 г. Инф. Тадышев Б., с. Балыктуюль Улаганского района РА.

Полевая запись автора 2006 г. Инф. Тадышева М.С., с. Улаган Улаганского района РА. 